\title{
A Rare Cause of Hypokalemia in the Emergency Department: Gitelman Syndrome
}

\author{
Gonullu Hayriye $^{1 *}$, Karadas Sevdegul ${ }^{1}$, Şahin Mustafa ${ }^{1}$ and Dursun Recep ${ }^{2}$ \\ ${ }^{1}$ Department of Emergency Medicine, Yuzuncu Yil University, School of Medicine, Turkey \\ ${ }^{2}$ Van Training and Research Hospital, Emergency Service, Turkey
}

\begin{abstract}
Gitelman's syndrome is an autosomal recessively inherited disease with a wide clinical spectrum usually seen in adolescents and adults. Patients have hypokalemia, metabolic alkalosis, hypomagnesemia and hypocalciuria together with normal blood pressure. Effect of GS on pregnancy is not known well. In this study, we presented a pregnant woman who experienced seizure due to electrolyte imbalance and diagnosed with Gitelman's syndrome.
\end{abstract}

\section{Introduction}

Gitelman Syndrome (GS) is an autosomal recessively inherited disease with a wide clinical spectrum, usually seen in adolescents and adults. It is reported that function loss develops in the sodium chloride $(\mathrm{NaCl})$ cotransporter system in the distal renal tubule as the result of SLC12A3 gene mutation [1]. Patients have hypokalemia, metabolic alkalosis, hypomagnesemia, and hypocalciuria together with normal blood pressure. Serum calcium (Ca), Phosphorous (P), Parathormone (PTH), and vitamin D3 levels are normal despite hypocalciuria [2]. Urinary $\mathrm{NaCl}$ loss and thereby hyperreninemia and hyperaldosteronism are seen [2]. Most of the patients are clinically asymptomatic, but some patients experience seizures, muscle weakness, cramps, episodic tetany, and paresthesia, and these complaints are reported to affect delivery in pregnant women $[3,4]$.

The diagnosis is usually made based on clinical features and laboratory and renal function tests in adulthood as the disease continues with recurrent episodes. Treatment is correction of electrolyte imbalance [5].

In this report, we present a 38-year-old pregnant woman who experienced seizure due to electrolyte imbalance and was subsequently diagnosed with GS.

\section{Case}

The pregnant patient with gestational age of 19 weeks was admitted to the emergency room with the complaint of seizure. On her physical examination, her general condition was moderate and she demonstrated confusion. Her abdominal examination revealed that her uterine dimensions were consistent with approximately the $20^{\text {th }}$ week of gestation. Her blood pressure was $110 / 70 \mathrm{mmHg}$, heart rate 84 bpm, and respiratory rate $20 / \mathrm{min}$. Other system findings were normal. She had used carbamazepine for epilepsy for 15 years and did not have any history of diuretic or laxative drug use. She had no complaints like vomiting or nausea. This was the patient's $8^{\text {th }}$ pregnancy: the 7 previous pregnancies resulted in 4 live births and 3 intrauterine losses. On obstetric ultrasonography, a live pregnancy of 19 weeks' gestation was detected. Electrocardiography revealed normal sinus rhythm. Laboratory test results are presented in table 1. Intravenous Potassium Chloride $(\mathrm{KCl})$ replacement therapy was started in the emergency room. No pathologies were detected on radiologic tests performed for differential diagnosis (abdominal ultrasonography, abdominal and cranial magnetic resonance imaging, echocardiography, and renal Doppler ultrasonography). The patient was diagnosed with GS based on these findings. Her general condition improved upon normalization of her electrolyte values. She was discharged with oral therapy (magnesium $[\mathrm{Mg}]$ b.i.d., Ca b.i.d., $\mathrm{K}$ once a day).

\section{Discussion}

Hypokalemia and hypomagnesemia may develop due to many reasons and may result in severe outcomes [6]. Maternal hypokalemia and hypomagnesemia are seen in a vast majority of pregnancies and usually result from gastrointestinal (vomiting, diarrhea, ulcerative colitis, malabsorption syndromes, malnutrition) and renal (diabetes mellitus, ketoacidosis, parenteral fluid treatment, diuretics, fasting, alcoholism, pyelonephritis) disorders. In addition, GS and Bartter Syndrome (BS) are shown among the causes of hypokalemia [79]. BS causes hypokalemia, hypocalcemia, hypercalciuria, and hypomagnesemia, and is inherited autosomal recessively, similar to GS. However, in contrast to GS, BS is usually diagnosed in the first year

\begin{tabular}{|l|l|l|}
\hline & Value & Normal range \\
\hline Potassium & $2.1 \mathrm{mmol} / \mathrm{L}$ & $3.5-5.1$ \\
\hline Magnesium & $1.24 \mathrm{mg} / \mathrm{dl}$ & $1.58-2.55$ \\
\hline Chlorine & $100 \mathrm{mmol} / \mathrm{L}$ & $98-110$ \\
\hline Calcium & $8 \mathrm{mg} / \mathrm{dl}$ & $8.4-10.3$ \\
\hline Urine calcium & $1.17 \mathrm{mg} / \mathrm{dl}$ & $6.7-21.3$ \\
\hline pH & 7.52 & $7.35-7.45$ \\
\hline Plasma renin activity & $16 \mathrm{ng} / \mathrm{mL} / \mathrm{saat}$ & $0,2-3,6$ \\
\hline Aldosterone & $260 \mathrm{pg} / \mathrm{mL}$ & $20-240$ \\
\hline $24-$ hour urine sodium & $100 \mathrm{mmol} / \mathrm{gün}$ & $30-300$ \\
\hline 24 hour urine potassium & $27,5 \mathrm{mmol} / \mathrm{gün}$ & $25-125$ \\
\hline Serum cortisol & $14 \mathrm{mcg} / \mathrm{dl}$ & $5-25$ \\
\hline Parathormone & $24,5 \mathrm{pg} / \mathrm{mL}$ & $11-67$ \\
\hline Vitamin D3 & $20 \mathrm{mcg} / \mathrm{L}$ & $10-60$ \\
\hline ACTH* & $30 \mathrm{pg} / \mathrm{mL}$ & $5-46$ \\
\hline Albumin & $3.1 \mathrm{~g}$ & $3.2-5.5$ \\
\hline Globulin & $3.4 \mathrm{~g}$ & $2.6-3.9$ \\
\hline Phosphorus & $4.3 \mathrm{mg} / \mathrm{dl}$ & $2.7-4.5$ \\
\hline
\end{tabular}

*Adrenocorticotropic hormone

Table 1: Laboratory characteristics of case.

*Corresponding author: Hayriye Gonullu, MD, Yuzuncu Yil Universitesi, Tip Fakultesi, Acil Tip A.D. Maras cad. 65300 Van / Turkey, Tel: +90 505 7672477; Fax: +90 432 2168352; E-mail: drhayriyegonullu@gmail.com

Received November 12, 2012; Accepted December 18, 2012; Published December 20, 2012

Citation: Hayriye G, Sevdegul K, Mustafa Ş, Recep D (2012) A Rare Cause of Hypokalemia in the Emergency Department: Gitelman Syndrome. J Clin Case Rep 2:231. doi:10.4172/2165-7920.1000231

Copyright: @ 2012 Hayriye G, et al. This is an open-access article distributed under the terms of the Creative Commons Attribution License, which permits unrestricted use, distribution, and reproduction in any medium, provided the original author and source are credited. 
Citation: Hayriye G, Sevdegul K, Mustafa Ş, Recep D (2012) A Rare Cause of Hypokalemia in the Emergency Department: Gitelman Syndrome. J Clin Case Rep 2:231. doi:10.4172/2165-7920.1000231

of life and leads to hypocalciuria [9-11]. In the presented case, absence of drug use, any known chronic diseases, diarrhea, and vomiting, and normal serum P, PTH and vitamin D3 levels despite hypocalciuria and normal blood pressure were suggestive of GS.

The effects of GS on pregnancy are not well known [11]. McCarthy et al. [1] reported that GS increased the risk of intrauterine growth retardation, oligohydramnios and abortion together with maternal morbidity, and thus stressed the importance of close follow-up of pregnant women with GS. Jones and Dorrell [12] published a 35-year-old case with GS who produced two normal births after two successive abortions. They suggested that controlling electrolyte levels within desired ranges is difficult in pregnant women with GS, and that electrolyte monitoring is not necessary for obstetric and neonatal outcomes [12]. Daskalakis et al. [7] reported that GS has no negative effects on pregnancy. Basu et al. [13] described a GS case in whom maintenance of physiologic $\mathrm{K}$ and $\mathrm{Mg}$ levels was difficult, but who nevertheless produced three successive normal pregnancies. Lakhi et al. [11] reported a pregnant GS case that resulted in intrauterine fetal death. In the study of Cruz et al. [4] evaluating GS cases, they reported that 20 of 35 patients had children, and of the 20 patients, 7 required intravenous fluid and electrolyte support, and complications like abortion and early delivery developed. In our study, the patient was gravida 8 , and 3 previous pregnancies had resulted in intrauterine fetal loss. This subject was diagnosed with GS in her last pregnancy.

\section{Conclusion}

In the presented case, although the exact cause of the intrauterine losses is not fully known, it cannot be claimed that they are not associated with the GS-related electrolyte imbalance. Thus, close monitoring of pregnant women with GS for electrolyte imbalance and electrolyte replacement when needed seem important for both maternal and fetal health. Nevertheless, further comprehensive studies are needed to investigate the effects of GS on pregnancy.

\section{References}

1. McCarthy FP, Magee CN, Plant WD, Kenny LC (2010) Gitelman's syndrome in pregnancy: case report and review of the literature. Nephrol Dial Transplant 25: $1338-1340$.

2. Akçakaya M, Oymak O, Ünal A (2008) Familial Hypokalemic Alkalosis: Gitelman's Syndrome. Turkish Nephrology, Dialysis and Transplantation Journal 18: 97-99.

3. de Haan J, Geers T, Berghout A (2008) Gitelman syndrome in pregnancy. Int J Gynaecol Obstet 103: 69-71.

4. Cruz DN, Shaer AJ, Bia MJ, Lifton RP, Simon DB, et al. (2001) Gitelman's syndrome revisited: an evaluation of symptoms and health-related quality of life. Kidney Int 59: 710-717.

5. Al-Ali N, Al Sayed A, Ramadan A (2008) A case of Gitelman's syndrome presenting with hypocalcemia. Kuwait Med J 40: 67-69.

6. Schwarz GJ (2004) Potassium. In Avner ED, Harmon WE, Niaudet P eds Pediatric Nephrology. Philadelphia: Lippincott Williams \& Wilkins.

7. Daskalakis G, Marinopoulos S, Mousiolis A, Mesogitis S, Papantoniou $\mathrm{N}$, et al. (2010) Gitelman syndrome-associated severe hypokalemia and hypomagnesemia: case report and review of the literature. J Matern Fetal Neonatal Med 23: 1301-1304.

8. Tong GM, Rude RK (2005) Magnesium deficiency in critical illness. J Intensive Care Med 20: 3-17.

9. Peters M, Jeck N, Reinalter S, Leonhardt A, Tönshoff B, et al. (2002) Clinical presentation of genetically defined patients with hypokalemic salt-losing tubulopathies. Am J Med 112: 183-190.

10. de Arriba G, Sánchez-Heras M, Basterrechea MA (2009) Gitelman syndrome during pregnancy: a therapeutic challenge. Arch Gynecol Obstet 280: 807-809.

11. Lakhi N, Jones J, Govind A (2010) Fetal demise despite normalisation of serum potassium in Gitelman syndrome. Case report and literature review. Aust N Z J Obstet Gynaecol 50: 301-302.

12. Jones JM, Dorrell S (1998) Outcome of two pregnancies in a patient with Gitelman's syndrome-A case report. J Matern Fetal Investig 8: 147-148.

13. Basu A, Dillon RDS, Roy Taylor, Davison JM, Marshall SM (2004) Is normalization of serum potassium and magnesium always necessary in Gitelman syndrome for a successful obstetric outcome? Br J Obstet Gynaecol 111: $630-634$. 